\title{
Sistematična preureditev mestnih ulic: prilagajanje podnebnim spremembam $z$ večfunkcionalnimi podnebno odzivnimi uličnimi vrtovi
}

Uvedba zelene infrastrukture je uveljavljen pristop $\mathrm{k}$ blaženju učinkov toplotnih otokov in poplav na mestnih območjih, saj lahko vpliva na pomembno znižanje lokalne temperature $\mathrm{v}$ mestu in zmanjšanje nevarnosti poplav. V članku je ulična krajina prepoznana kot pomembno območje posegov za prilagajanje podnebnim spremembam, pri čemer ti posegi temeljijo na zeleni infrastrukturi, ki omogoča prijetnejše okolje za človekovo aktivnost in mobilnost $\mathrm{v}$ mestih, hkrati pa je pomemben blažilec toplote. Avtorji predlagajo rešitev, ki združuje nekatere ključne prvine, ki bi bile lahko podlaga vsem prihodnjim oblikovalskim posegom $\mathrm{v}$ javni prostor (ulično krajino), in spodbuja ureditev mestnega okolja, ki se resnično odziva na podnebne spremembe. Te prvine vključujejo omejitev neprepustnih površin samo na nujna območja, decentralizirano gospodarjenje $\mathrm{z}$ vodo na podlagi deževnih vrtov, nezahtevno vzdrževanje, estetske zasaditve, ki krepijo biotsko raznovrstnost, in senzorsko spremljanje parametrov toplotnega udobja za izboljšanje ukrepov. Rešitev vključuje uporabo poceni senzorjev za zbiranje podatkov o toplotnem udobju, na podlagi katerih se lahko določijo območja mestnih toplotnih otokov. Predlagano je tudi odločevalsko orodje, ki temelji na geografskem informacijskem sistemu (GIS) in zbira podatke, kot so temperatura, stopnja prekritosti površja in poplavno tveganje ter podatki, ki se nanašajo na lokacijo komunalne infrastrukture, promet in prostorsko ureditev. Opisana je poskusna uporaba predlagane metodologije v okviru trajnega projekta prilagoditve podnebnim spremembam, ki ga financira avstrijska vlada.

Ključne besede: javni prostor, podnebne spremembe, gospodarjenje s padavinsko vodo, ulično odvodnjavanje, senzorska tehnologija in digitalizacija 


\section{Uvod}

Kako obvladovati vplive podnebnih sprememb na mestnih območjih je izziv, s katerim se nenehno spopadajo mesta po vsej Evropi in drugje po svetu. Odločevalci proučujejo nepredvidljive vremenske razmere, ki povzročajo mestne toplotne otoke in poplave ter posledično družbeno-gospodarsko škodo. Vplive podnebnih sprememb v mestih krepita gosta pozidava in širjenje neprepustnih površin, ki zadržujejo toploto in hkrati preprečujejo naravno kroženje vode. Navedeno zlasti v mestnih središčih zmanjšuje toplotno udobje, poleg tega povečuje obremenjenost kanalizacijskega omrežja, zaradi česar se zlasti ob močnem deževju odpadna voda izliva v naravne vodotoke in jih onesnažuje.

Pri obvladovanju podnebnih sprememb posegi, ki temeljijo na zeleni infrastrukturi, omogočajo trajnosten način blaženja teh sprememb in izboljšajo mikroklimo v mestih. Ozelenjevanje mest je postal priljubljen izraz $\mathrm{v}$ povezavi $\mathrm{z}$ bivalno prijaznejšimi mesti 21. stoletja, vendar je bilo pri sistematizaciji in optimizaciji tovrstnih posegov za izboljšanje dolgoročne učinkovitosti in donosnosti naložb narejenega le malo napredka. Navedeno je deloma posledica večplastnosti in kompleksnosti obravnavane problematike, ki zahteva usklajeno sodelovanje številnih deležnikov, zlasti pri uporabi načrtovalskih orodij in procesov.

V članku avtorji predlagajo večfunkcionalen pristop, ki omogoča oblikovanje dobre prakse za bolj sistematično vključevanje zelene infrastrukture v mestno tkivo. Posebna pozornost je namenjena dejavnikom, ki povzročajo učinek mestnega toplotnega otoka, pri čemer se problematična območja določijo z mobilnimi senzorji. Neprepustne vodoravne mestne površine brez zaznane prometne funkcije (mrtva območja) se izberejo za preureditev z zeleno infrastrukturo v obliki deževnih vrtov, ki so prepoznani kot pomembna urbanistična prvina. Predstavljeni pristop zagotavlja neposreden in trajnosten način spopadanja z vzroki za nastanek mestnih toplotnih otokov, hkrati pa spodbuja pozitivnejši in neposrednejši človeški stik z naravo ter izboljšuje biotsko raznovrstnost mestnega okolja.

Da bi dosegli predlagano raven večfunkcionalnosti, je bil ustanovljen raziskovalni konzorcij v obliki delovne skupine, ki združuje strokovnjake $z$ različnih področij (krajinsko načrtovanje, hidrologija, urbanistično in prostorsko načrtovanje, prometno načrtovanje, informatika in ekologija). Z aktivno uporabo multidisciplinarnega pristopa $\mathrm{k}$ oblikovanju ukrepov izboljšav je cilj delovne skupine razviti zares trajnostne rešitve za spopadanje s podnebnimi spremembami. Njeno delo je inovativno $\mathrm{v}$ smislu uporabe večfunkcionalnega pristopa $\mathrm{k}$ ureditvi mestne zelene infrastrukture ter multidisciplinarnega razvoja in uporabe predstavljene metode.

\subsection{Pomen uličnega prostora}

$\mathrm{Na}$ območjih, ki so najbolj izpostavljena učinkom mestnega toplotnega otoka in poplavam zaradi močnih nalivov, je običajno obseg mogočih ukrepov najbolj omejen. Zlasti v mestnih središčih, kjer je čedalje manj razpoložljivega prostora, saj se ta vztrajno krči, je velik delež neprepustnih površin, zaradi česar prst izgublja svojo naravno funkcijo, površine pa se ne morejo naravno ohlajati. Čeprav je zelena infrastruktura trajnostna oblika blaženja podnebnih sprememb, je zanjo potrebnega zelo veliko prostora. Oblikovalci morajo zato ulični prostor natančno proučiti ter določiti in prerazporediti najpomembnejše funkcije na njem. Ugotoviti morajo, kje so ukrepi najbolj potrebni in katera vrsta zelene infrastrukture je najprimernejša za posamezno območje. Mesta želijo povečati pozitivne učinke zelenih naložb in zmanjšati njihove negativne vidike, kar zahteva primerna odločevalska orodja in spodbujanje večfunkcionalnosti (Monteiro idr., 2020).

O možnostih vertikalnega ozelenjevanja fasad, s katerimi se prihrani prostor, kot načinu prilagajanja podnebnim spremembam v mestih je bilo opravljenih že veliko raziskav, kljub ugotovljenim prednostim pa ima takšno ozelenjevanje tudi nekatere pomanjkljivosti (Manso idr., 2015). V izoblikovani mestni strukturi, v kateri je staro mestno jedro zaščiteno z odloki, v skladu s katerimi se morata ohranjati njegova kulturna dediščina in identiteta, so možnosti za ureditev zelene infrastrukture, kot so vertikalni ali strešni vrtovi, omejene (Pansinger in Förster, 2018). Dokler ne bo razvita primerna tehnologija, ki bo v skladu z zahtevami po ohranjanju zgodovinskih objektov in območij, so potrebni drugačni pristopi. Pregled literature kaže, da se odpornost proti podnebnim spremembam večinoma dosega z večjimi sistemi, na ravni stavb pa se to področje šele razvija (Kristl idr., 2020). Raziskave kažejo, da lahko s kvadratnega metra zelene strehe izhlapita po dva litra vode na dan, poleg tega lahko enaka površina zelene strehe zadrži $10 \mathrm{~g}$ prašnih delcev in absorbira $375 \mathrm{~g} \mathrm{CO}_{2}$ na leto. Zelene strehe delujejo tudi kot zvočna izolacija, ki zmanjšuje ulični hrup, in prispevajo $\mathrm{k}$ energijski varčnosti objektov (Willenbrock, 2020). Bolj zeleno mestno okolje je prijetnejše in povečuje kakovost urbanih ambientov (Kozamernik idr., 2020). Čedalje večje spodbujanje aktivne mobilnosti in kakovostnega javnega prostora v zadnjem času (Markvica idr., 2020) zahteva ponoven premislek o ureditvi uličnega prostora. Pešci in kolesarji okolje doživljajo dosti bolj živo kot vozniki ali uporabniki javnih prevoznih sredstev. Zgradba ulične krajine se opisuje kot pomemben dejavnik privlačnosti mest in njihove prijetnosti za bivanje (Gehl, 2015). Visoke temperature (mestni toplotni otok) ljudi odvračajo od aktivne mobilnosti in slabšajo kakovost javnega prostora. $\mathrm{V}$ prihodnje je treba poskrbeti, da so mesta zanimiva in privlačna, hkrati pa morajo prispevati $\mathrm{k}$ blaženju vplivov podnebnih sprememb. 


\subsection{Dajanje prednosti večfunkcionalnim zelenim posegom na tleh}

Toplotni zemljevidi mest kažejo, da so vodoravne površine na mestnih območjih (slika 1), kot so strehe in ceste, pogosto najbolj izpostavljene sončnemu obsevanju in imajo pomembno vlogo pri zadrževanju toplote $\mathrm{v}$ mestu. $V$ zadnjem času se gradnja zelenih streh spodbuja z raznimi subvencijami (internet 1), ki pa ne upoštevajo lokacije ali lokalnih razmer. Poleg tega tovrstna zelena infrastruktura trenutno ni primerna za dvokapnice ali strehe stavb, ki spadajo v zaščiteno kulturno dedišcino. Enako velja za vertikalno ozelenjevanje. Dodatna ovira je, da je za takšne ukrepe potrebna zasebna finančna pobuda. Zasebni lastniki se za naložbe v zeleno infrastrukturo odločajo predvsem, kadar jim to prinaša finančne prednosti. V zvezi $s$ tem se zastavlja vprašanje, ali takšen pristop zagotavlja optimalne in učinkovite naložbe $\mathrm{v}$ zeleno infrastrukturo kot ukrep blaženja vplivov podnebnih sprememb. Zakaj občine ne sprejmejo ustrezne politike za reševanje te problematike? Te namreč upravljajo ceste in mnoga parkirišča, ki zadržujejo velik del toplote $\mathrm{v}$ mestih. Izvajanje ukrepov blaženja vplivov podnebnih sprememb na občinskih ulicah posledično ni tako zapleteno kot ozelenjevanje zasebnih stavb. Hkrati ulice omogočajo mobilnost vseh v mestu, tudi pešcev in kolesarjev. Ureditev ulic je zelo pomembna tudi za privlačnost mest $\mathrm{z}$ vidika človeškega merila (Gehl, 2015). Mestni toplotni otoki dodatno zmanjšujejo privlačnost mestnih območij, zato je nujno, da se z njimi spoprimemo tam, kjer se pojavijo: $\mathrm{v}$ uličnem prostoru. Glavni cilj mora biti zmanjšanje asfaltnih in betonskih površin, ki zadržujejo toploto, hkrati pa je treba omogočiti zadostno mobilnost in bivalno kakovost na teh območjih ter izboljšati njihovo trajnostnost. Na podlagi navedenega lahko oblikujemo pametnejša, bolj zelena in bolj zdrava mesta, ki jih odlikuje ravnovesje med energijsko porabo in funkcijo, okoljem in estetiko ter tehnologijo in naravo, $\mathrm{v}$ katerih so ljudje in njihove potrebe v ospredju ter za katera je značilna prostorska preobrazba nekdanjih dvodimenzionalnih ulic (Pansinger, 2018). Zato je smiselno, da se v začetni fazi izvajanja ukrepov prilagajanja podnebnim spremembam daje prednost temu delu mestnega tkiva.

Mestni prostor je torej treba na novo proučiti in prepoznati možnosti, ki so bile prej morebiti prezrte. Na mestnih območjih poleg pomanjkanja prostora številni dejavniki, kot so čedalje večja prekritost tal, gost promet in podzemna infrastruktura, ovirajo ureditev obsežnejših zelenih površin. Posledično se veča potreba po manjših in prožnejših rešitvah (npr. parkletih ali mobilnih drevesih) kot posebnih oblikah zelene urbane akupunkture. Manjši posegi lahko torej v mestnem prostoru omogočijo nov pretok energije med zelenimi in pozidanimi območji v mestu, ki sestavljajo tako imenovano dvojno otočje (Christiaanse, 2018: 45).

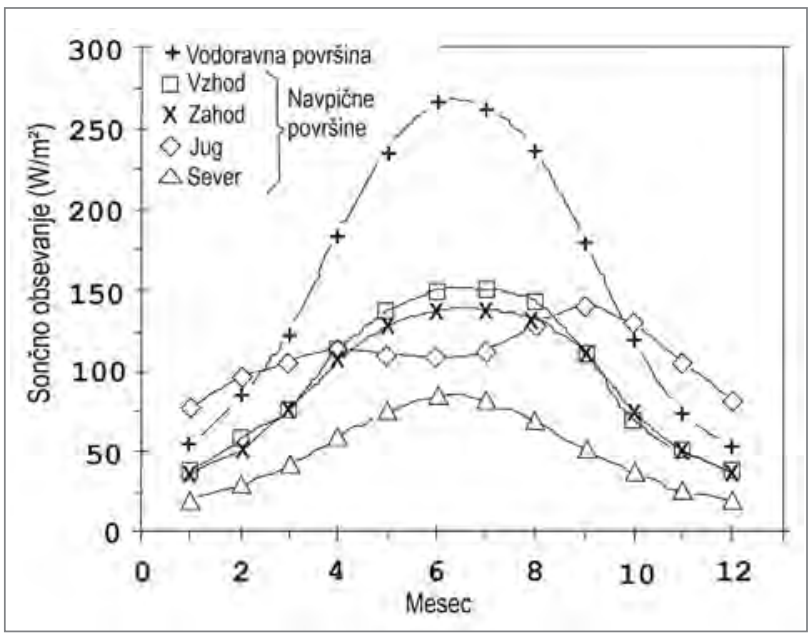

Slika 1: Skupno sončno obsevanje na vodoravnih in navpičnih površinah z različno usmeritvijo v Istanbulu (vir: Kaynakli, 2011)

$\mathrm{V}$ trenutnem diskurzu o skrb vzbujajoči krnitvi biotske raznovrstnosti po vsem svetu (IPBES, 2019) bi bilo treba kakovostne zelene mestne površine prepoznati kot sredstvo za izboljšanje dejanske biotske raznovrstnosti v mestih in za to, $\mathrm{da}$ se prebivalce pritegne $\mathrm{k}$ ukrepanju, zlasti $\mathrm{z}$ večjim izpostavljanjem problema. Navedeno se lahko doseže tako, da se posebna pozornost nameni tudi kakovosti zelene infrastrukture, ne samo njeni količini. V poročilu organizacije IPBES (2019) je izpostavljen pomen naravnih rešitev, zdravih mestnih okolij, izboljšanega dostopa do zelenih površin in ekološke povezanosti mestnih prostorov. Mešane zasaditve avtohtonih rastlinskih vrst imajo lahko v nasprotju s trenutno prevladujočo monokulturno urbano zasaditvijo močan in dolgotrajen pozitiven vpliv na urbano ekologijo, saj so odpornejšse proti boleznim, poleg tega je zanje potrebnih manj gnojil in pesticidov (Isbell idr., 2017). Zato se lahko tudi žuželke in drugi opraševalci nemoteno vrnejo $\mathrm{v}$ urbano okolje in omogočajo vpogled v delovanje narave. Izkušnje kažejo, da mešane zasaditve močno povečajo raznovrstnost žuželk (Mody idr., 2020), kar lahko opazi tudi javnost. $S$ tovrstno zeleno infrastrukturo lahko torej javnost ozaveščamo o tem, da biotska raznovrstnost ne zagotavlja samo preživetja človeške rase, ampak tudi prijetno bivalno okolje v mestih.

\section{Metoda}

V prejšnjem poglavju so bile opisane prvine, ki jih je treba vključiti v sistem podnebno odzivnih uličnih vrtov, pri čemer je treba odločitve o tem, kako in kje umestiti katero zeleno infrastrukturo, formalizirati v okviru sistematiziranega postopka (Koc idr., 2018). Potrebe po prostoru (npr. za promet, ljudi in storitve) se morajo izražati v strukturi in vsebini podatkov ter ne nazadnje v končnem orodju. Pri odločanju o nujnosti zelenega prostorskega posega je treba upoštevati izvedljivost 
izbranih ukrepov. Nekateri uradi in mesta so izdelali orodja, ki omogočajo izbor pilotnih projektov na podlagi sodelovanja skupnosti ali prikaz skupnih koristi zelenih prostorskih posegov (internet 2). Navedeni pristopi upoštevajo dva ali tri vidike ali funkcije, ne omogočajo pa objektivnega izbora posegov na podlagi lokalnih razmer in prostorskega okvira, $\mathrm{v}$ katerem naj bi se izvajali.

Trenutno se podatki o toplotnem udobju zbirajo predvsem z daljinskim zaznavanjem, infrardečimi letalskimi posnetki in/ ali satelitskimi posnetki (Xuexiu idr., 2020), za uspešno rešitev pri zbiranju podatkov o temperaturah v mestih pa so se izkazali tudi brezpilotni letalniki (Soto-Estrada idr., 2017). Zbrani podatkovni nizi se uporabljajo za izdelavo in kalibracijo urbanih podnebnih modelov. Ti pristopi imajo nekatere pomanjkljivosti. Letalski posnetki, tudi tisti, narejeni z brezpilotnimi letalniki, omogočajo samo prikaz razmer v danem trenutku, lokalno podnebje pa se nenehno spreminja. Navedena metoda torej ne upošteva te dinamike. Podatki o spreminjanju temperaturnih razmer v daljših obdobjih bi omogočili bolj dodelan pristop $\mathrm{k}$ uvajanju ukrepov in spremljanje njihovih vplivov. Izhodišče takšnega pristopa je petdimenzionalni model, iz katerega so razvidni vsestranskost zelenih površin ter sedanje in prihodnje potrebe mestnih prebivalcev (slika 2). Model temelji na načelih urejanja zelene infrastrukture, ki so jih predstavili Monteiro idr. (2020).

Na podlagi navedenega modela je bil razvita sistematična in ponovljiva metoda, imenovana podnebno odzivni ulični vrtovi, katere glavni cilj je izboljšati proces in končni rezultat urejanja zelene infrastrukture na mestnih območjih. Avtorji so določili in združili glavne prvine sistema podnebno odzivnih uličnih vrtov, da bi zagotovili čim višjo stopnjo večfunkcionalnosti. Predlagana metoda bi bila lahko izhodišče za prihodnje oblikovalske posege, pri katerih bi bili ukrepi prilagajanja podnebnim spremembam vključeni v oblikovanje javnega prostora. $S$ tem bi se poleg upoštevanja estetskih vidikov zagotovila čim večja funkcionalnost izvedenih posegov, zlasti pri preureditvi obstoječega mestnega tkiva in pri novogradnjah.

Postopek, ki omogoča doseganje zgoraj navedenega cilja, vključuje naslednje faze:

- urbanistična analiza in določanje območij, primernih za ukrepanje, $\mathrm{v}$ obstoječi in načrtovani prostorski ureditvi na podlagi podatkov GIS, letalskih posnetkov in prostorskih aktov;

- razvoj cenovno ugodne metode za zbiranje podatkov o toplotnem udobju (podatki o lokalnih temperaturah in vlagi), na podlagi katerih se določi, kje so potrebni ukrepi, ki temeljijo na uporabi zelene infrastrukture, za prilagajanje podnebnim spremembam. Ti podatki so tudi del vhodnih podatkov za odločevalsko orodje, ki temelji

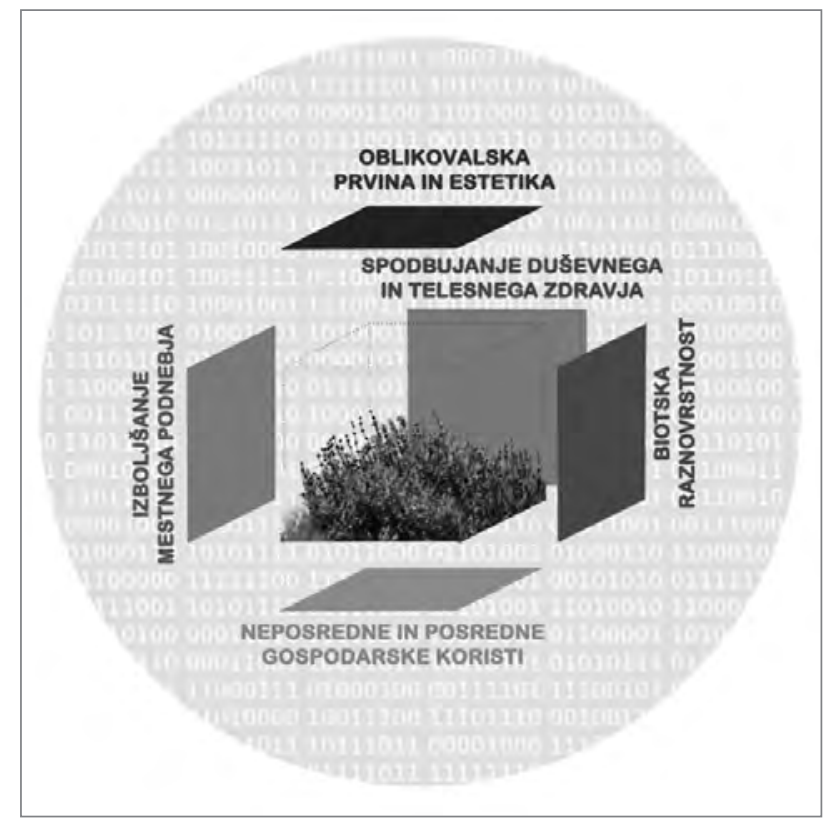

Slika 2: Petdimenzionalni model (vir: avtorji)

na GIS, poleg tega omogočajo spremljanje učinkovitosti posegov po njihovi izvedbi;

- oblikovanje odločevalskega orodja na podlagi modela ocene primernosti, ki temelji na obstoječi tehnologiji ter združuje predhodne podatkovne nize (npr. karte komunalne infrastrukture, podatke o gostoti prometa, vegetacijske karte, zakonodajo in prostorske modele) in dodatno zbrane podatke (npr. o toplotnem udobju); izdelano orodje podpira odločanje o uvedbi podnebno odzivnih vrtov v ulično krajino;

- določitev in vključitev glavnih prvin blaženja učinkov podnebnih sprememb, kot so ozelenitev cestnih površin, kjer je to primerno in nujno, vpeljava decentraliziranega gospodarjenja s površinskimi vodami in zasaditev kakovostnih avtohtonih rastlinskih vrst, ki niso zahtevne za vzdrževanje, podpirajo biotsko raznovrstnost in prispevajo $\mathrm{k}$ lepšsemu mestnemu okolju.

Načrtna ozelenitev neprepustnih površin ali sprememba obstoječih zelenih površin $\mathrm{v}$ podnebno odzivne ulične vrtove ima več funkcij in pozitivnih vplivov: površje se naravno ohlaja, poskrbljeno je za trajnostno gospodarjenje s padavinsko vodo in ulično odvodnjavanje, izboljšata se vidna in zvočna podoba ulice, javni prostor postane ljudem bolj všeč, poveča pa se tudi biotska raznovrstnost območja. $S$ stalnim merjenjem temperature zraka, vlage in količine padavin s senzorsko tehnologijo, razvito posebej v ta namen, se lahko pozitivni vplivi podnebno odzivnih uličnih vrtov na bližnjo okolico tudi kvantitativno preverjajo, omenjeni podatki pa so ves čas dostopni v namensko razviti aplikaciji. 


\section{Rezultati}

V nadaljevanju so predstavljeni naslednji rezultati:

- razvoj primernih senzorjev in aplikacije za zbiranje in širjenje podatkov o toplotnem udobju; - izdelava modela za oblikovanje odločevalskega orodja, ki temelji na GIS;

- opredelitev računalniško podprte metode vključevanja gospodarjenja s površinskimi vodami;

- določitev oblikovalskih meril za ustrezno zasaditev rastlin in uporabo prsti, prilagojenih izmenjavanju sušnih obdobij in občasnih poplav ter zahtevnim urbanim pogojem (npr. onesnaženim površinskim vodam);

- zagotovitev poskusne izvedbe opisanega večfunkcionalnega pristopa na mestnem območju;

- izdelava splošnega zemljevida območij z izrazitim tveganjem za pregrevanje in poplavljanje ter vključitev zemljevida $\mathrm{v}$ prostorske akte.

\subsection{Razvoj senzorjev za zbiranje podatkov o toplotnem udobju}

Pri razvoju senzorjev so avtorji proučevali možnosti za neprekinjeno in dolgoročno zbiranje podatkov o temperaturah. Z vidika stroškov se je vzpostavitev obsežne mreže senzorjev za zbiranje podatkov o temperaturah in vlagi izkazala za neprimerno. Namesto tega so avtorji predlagali uporabo manjšega števila mobilnih senzorjev z GPS-sledilniki, ki omogočajo zbiranje podatkov na širšem območju. Senzorji bi se namestili na motorna kolesa pismonoš ali drugih dostavljavcev, kar bi omogočilo redno zbiranje podatkov po celotnem mestu. $\mathrm{Na}$ svoja kolesa bi jih lahko namestili tudi prebivalci, kar bi zagotovilo dodaten vir podatkov, hkrati pa bi se med ljudmi povečalo zavedanje o podnebnih vplivih (slika 3).

Trenutni prototip mobilnih senzorjev zbira podatke o temperaturi in vlažnosti zraka, ki sta pomembna kazalnika toplotnega udobja na mestnih območjih (slika 4). Vgrajen ventilator omogoča enakomerno izmenjavo zraka z okolico in poveča natančnost merjenja. Meritve klasičnih senzorjev, ki so neposredno izpostavljeni soncu, namreč ne pokažejo pravilne temperature v izbranem prostoru. Podatki se prenašajo prek mobilnega telefonskega omrežja z uporabo tehnologije NB-IoT, ki je bila razvita za energijsko varčen prenos podatkov. Senzorji, ki jih napajajo baterije, lahko tako neprekinjeno zbirajo in prenašajo podatke v daljšem obdobju. Storitev NB-IoT je pri večini ponudnikov na voljo po ugodnih cenah. Prvi prototipi se že uporabljajo, podatki pa se urejajo v posebni aplikaciji (climapp), ki se lahko naloži na vsak pametni telefon. Rezultati so prikazani na prosto dostopnih spletnih uličnih zemljevidih, na katerih
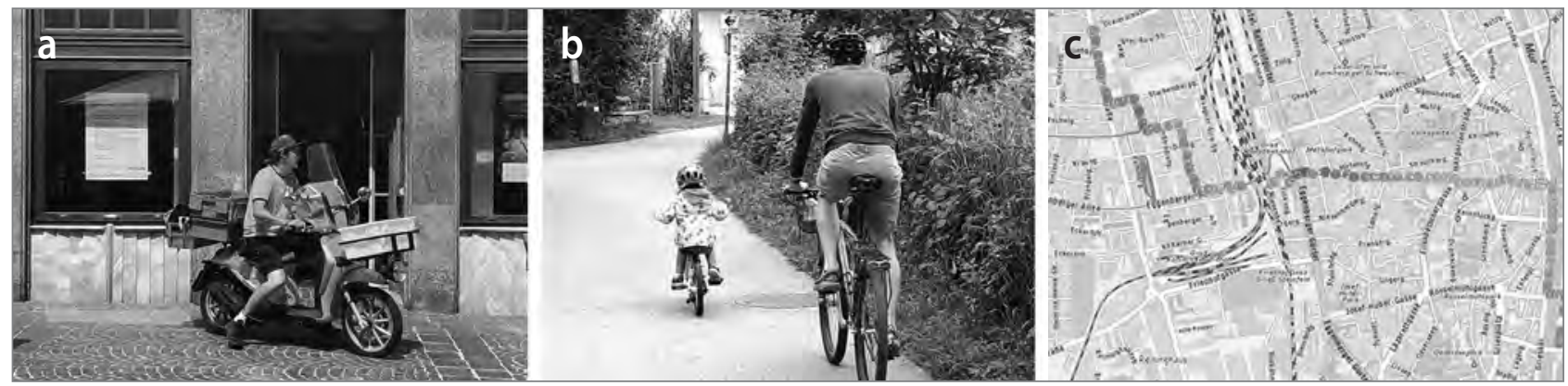

Slika 3: (a) Senzorji NB-loT, nameščeni na motorna ali navadna kolesa, sestavljajo mobilno omrežje za neprekinjeno in poceni zbiranje podatkov o toplotnem udobju v javnem prostoru; (b) senzorji NB-loT se lahko uporabljajo na katerem koli kolesu; (c) temperaturne razlike v razponu 2-3 ${ }^{\circ} \mathrm{C}$, označene na cestnem zemljevidu v temno in svetlo sivih odtenkih (vir: avtorji)

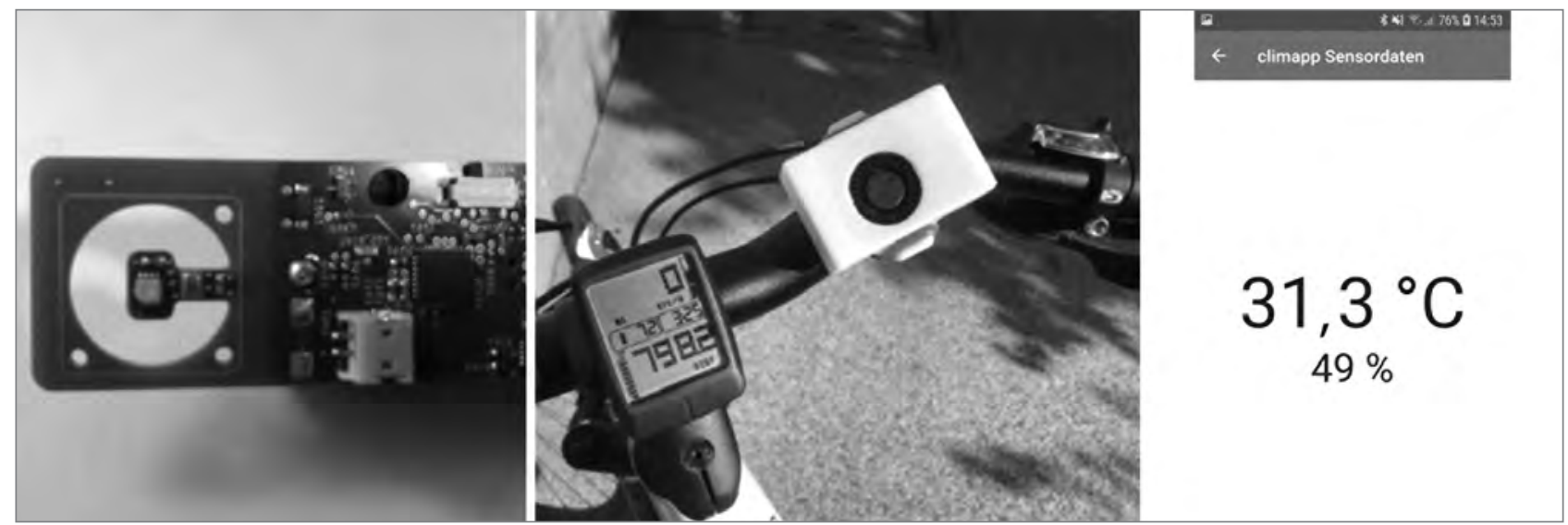

Slika 4: Prototip senzorja, ki omogoča mobilno zbiranje podatkov o lokalnem podnebju (vir: avtorji) 


\section{1. faza analize}

Kje je zelena infrastruktura potrebna?

- določanje MTO na podlagi podatkov o toplotnem udobju

- ocena verjetnosti hudourniških poplav

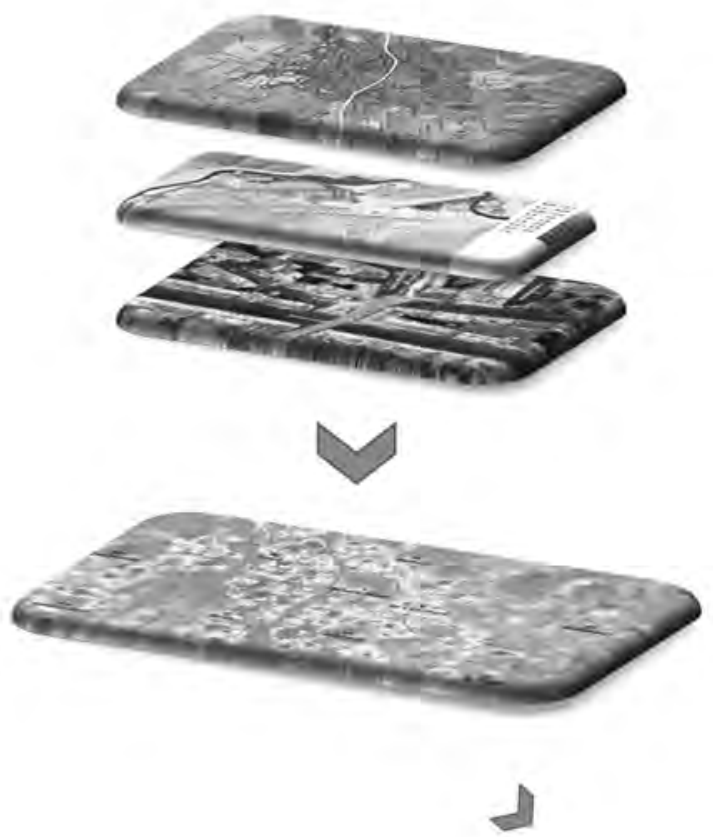

\section{2. faza analize}

Kje je ureditev zelene infrastrukture tehnično mogoča in primerna?

- hidrološka analiza

- karta komunalne infrastrukture

- register dreves in druge vegetacije

- usmeritev cest (proti severu ali jugu)

- razmerje med višino stavb in širino ulic

- stopnja prekritosti tal

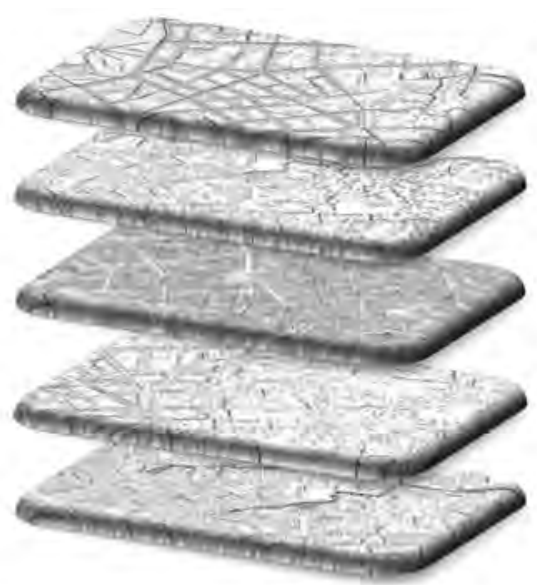

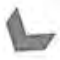

\section{Analiza prekrivanja obteženih slojev za določanje primernosti lokacije}
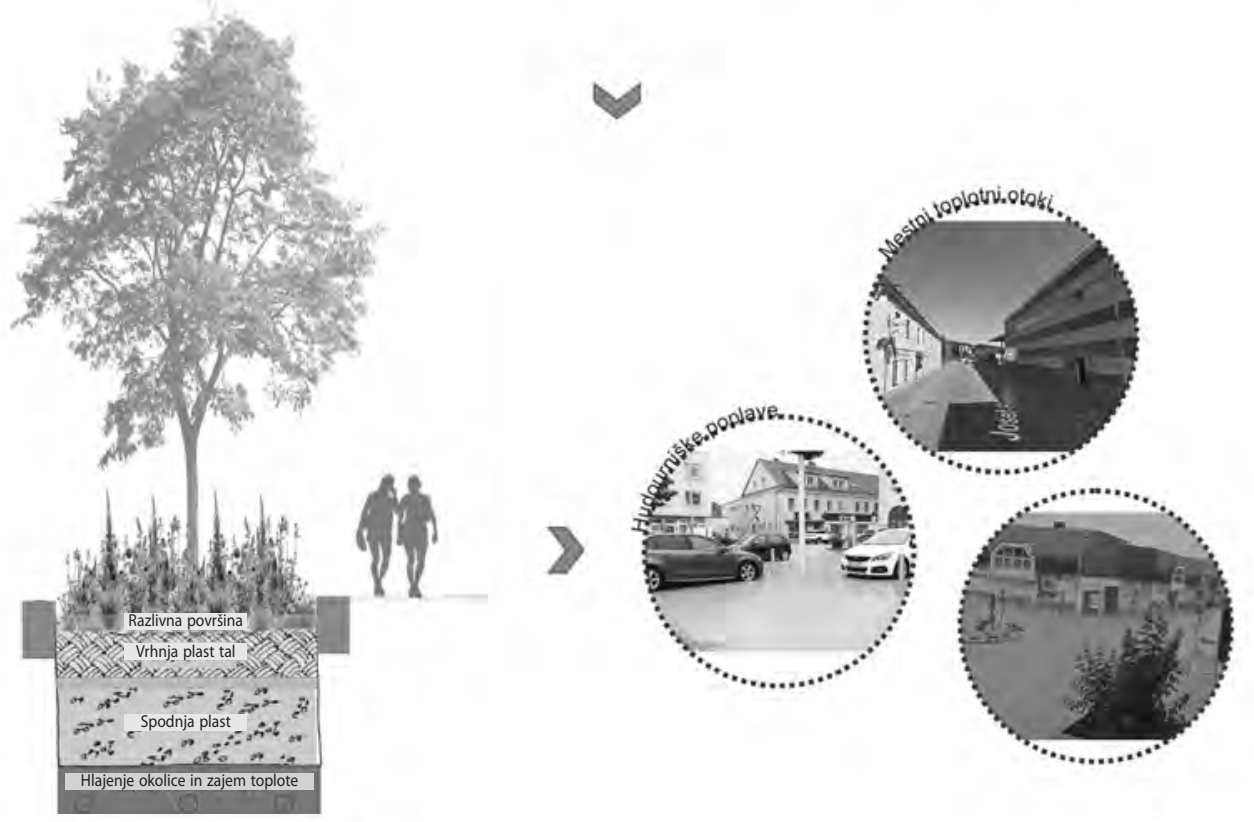

Slika 5: GIS-orodje za presojo primernosti območij za umeščanje večfunkcionalnih uličnih vrtov v mestni prostor (vir: avtorji) 
so $\mathrm{z}$ različno barvo označene temperaturne razlike $\mathrm{v}$ uličnem omrežju (zelena $=$ hladno, rdeča $/$ oranžna $=$ vroče $).$ Ta metoda omogoča poceni ter neprekinjeno in zanesljivo pridobivanje podatkov o toplotnem udobju, s katerimi se lahko posodablja omenjeno GIS-orodje.

\subsection{Model GIS-orodja za presojo primernosti}

Mestna območja so zelo kompleksni sistemi, s svojo rastjo in večjo gostoto pa postajajo še kompleksnejši. Za obvladovanje te kompleksnosti je bilo treba razviti metode, ki omogočajo ustrezno obdelavo zanesljivih in dodelanih prostorskih podatkov, ki se sproti posodabljajo. Posledično se čedalje bolj uporabljajo GIS, ki so bili razviti prav za obvladovanje kompleksnosti prostorskih podatkov in omogočajo obveščeno odločanje na vseh področjih urejanja mestnega prostora. GIS so pomembni zato, ker na enem mestu združujejo ogromne količine podatkov, potrebnih za uravnoteženo določanje prednostnih nalog in reševanje raznih problemov, tudi za optimizacijo uvajanja novih zelenih površin. GIS so se že izkazali za uporabne pri določanju primernih lokacij za urejanje deževnih vrtov (Fuskova, 2017).

Poenostavljen diagram na sliki 5 prikazuje predlagani model, ki združuje različne obstoječe podatke (npr. karto komunalne infrastrukture, podatke o razmerju med višino stavb in širino ulic, stopnji neprepustnosti in prometnih tokovih ter standarde, ki se nanašajo na dimenzioniranje cest) in dodatne podatke o toplotnem udobju, pridobljene z omenjenimi senzorji. Potem ko se zberejo ustrezni podatki, se izvede analiza prekrivanja obteženih kriterijev, s katero se na podlagi izbranih lastnosti določijo območja, primerna za ureditev zelenih površin kot ukrep odzivanja na podnebne spremembe. $S$ to metodo lahko urbanisti ugotovijo, kje so ukrepi potrebni in kje jih je mogoče izvesti. Poleg tega omogoča sprejemanje usklajenih in informiranih odločitev o ukrepih, povezanih z urejanjem zelenih površin, kar zagotavlja večjo učinkovitost izvedenih posegov, večjo donosnost naložb in večjo preglednost postopkov.

\subsection{Vključitev podatkov, potrebnih za decentralizirano gospodarjenje s padavinsko vodo}

Spremembe v vodnem krogu so med ključnimi posledicami čedalje večje neprepustnosti površin (Shuster idr., 2005). Ozelenjevanje neprepustnih mestnih površin omogoča, da se prst znova aktivira in hladi okolico z evapotranspiracijo, ki blaži učinke mestnega toplotnega otoka. Poleg tega zmanjšuje vplive hudih nalivov, ki so prav tako posledica podnebnih sprememb. Ocena hidroloških procesov se nekoliko razlikuje od narave drugih vhodnih podatkov za odločevalsko orodje, saj je treba na primer najprej izračunati vpliv padavin na urbani sistem. Vrsta izračuna je močno odvisna od proučevanega območja in njegove prostorske zgradbe ter od cilja raziskave. Za oceno vodne bilance mestnega območja (Sprung idr., 2017) zadostujejo preprosta orodja, za oceno časovnega in prostorskega poteka mestnih poplav pa so potrebna napredna simulacijska orodja (Krebs idr., 2014a). Cilj raziskave je poleg tega neposredno povezan s potrebnimi podatki in pogosto je treba za hidrološko presojo pred namestitvijo zelene infrastrukture in po njej uporabiti razna orodja za presojo (Krebs idr., 2013, Krebs idr., 2014b, Leimgruber idr., 2019). Rezultati opravljenih izračunov (npr. zemljevidi poplavnih območij) se nato uporabijo kot vhodni podatki za odločevalsko orodje, na podlagi katerih se določijo najboljše lokacije in sestava tal za ureditev podnebno odzivnih uličnih vrtov.

\subsection{Izbor primernih zasaditev za podnebno odzivne vrtove}

Niso vse zelene površine ustvarjene enako (Wood idr., 2018). V mestnem okolju ima pomembno vlogo tudi kakovost zelenih prostorov, ne samo njihova količina. Zelena infrastruktura $\mathrm{v}$ mestih mora izpolnjevati več meril, povezanih z zasaditvami $\mathrm{v}$ javnem prostoru. Mestne zasaditve morajo biti privlačne na pogled in se morajo biti sposobne prilagajati zahtevnim podnebnim in drugim razmeram (visoke ali nizke temperature, promet, odpadki, prebivalci in hišni ljubljenčki), hkrati pa morajo biti čim manj zahtevne za vzdrževanje, da oddelkom mestne uprave, ki imajo za ta namen malo finančnih sredstev, ne povzročajo še več stroškov. Vse našteto je zelo težko zagotoviti, zaradi česar so v preteklosti prevladovale monokulturne zasaditve, ki pa ne morejo več izpolnjevati zahtev sodobnih mestnih zelenih površin.

Na podlagi petdimenzionalnega modela, predstavljenega na sliki 2, imajo podnebno odzivni ulični vrtovi naslednje glavne funkcije:

- hlajenje in zagotavljanje sence;

- omogočanje decentraliziranega gospodarjenja s površinskimi vodami;

- krepitev biotske raznovrstnosti v mestu;

- izboljšanje zdravja in počutja ljudi.

Zasaditve, ki lahko izpolnjujejo večino zgornjih meril, se zgledujejo po t. i. gramoznih vrtovih, na katere je širšo javnost najprej opozorila britanska vrtnarka Beth Chatto (2000). Ta je na enem najbolj sušnih območij Anglije brez urejenega namakanja ter $s$ siromašno in zelo prepustno prstjo poskušala urediti vrt. To ji je tudi uspelo: ustvarila je slikovit vrt z bogato in privlačno mešanico rastlin, ki so odporne proti suši in jih ni treba nikoli zalivati. Njeno metodo posnemajo v številnih vrtovih po vsem svetu, čedalje bolj pa se prepoznavajo tudi njene prednosti pri 
zasaditvah v javnem prostoru (Fallast, 2018; slika 6). Razne rastlinske združbe $\mathrm{v}$ javnem prostoru so ponavljajoča se tema del številnih avtorjev (npr. Hitchmough, 2017, in Dunnett, 2019). Zlasti Dunnett (2019) je dokazal, da se estetika in večja funkcionalnost, dosežena z zajetjem in zadrževanjem padavinske vode, nikakor ne izključujeta. Privlačno in za vzdrževanje nezahtevno alternativo klasičnim tratam je predstavil Smith (2019). Zahteva uporabo nizkih ali pritlikavih rastlinskih vrst (npr. pritlikave kamilice) ter združuje hortikulturno prakso in ekologijo. Končni rezultat je trata brez trave, ki je ni treba kositi ali gnojiti. Na podlagi navedenih metod je bil izdelan seznam rastlin, ki izpolnjujejo glavne omenjene funkcije in vključujejo avtohtone vrste, kjer je to primerno. Seznam je podlaga za oblikovanje podnebno odzivnih uličnih vrtov ter je namenjen izvedbi in spremljanju $\mathrm{v}$ začetnih študijah primera. Vsi zainteresirani ga lahko dobijo pri avtorjih, in to na podlagi pisne prošnje.

Zaradi visoko prepustne zgradbe tal (razmerje peska in rodovitne zemlje je 50 : 50) je tovrstna zasaditev idealna za sisteme za gospodarjenje s padavinsko vodo (deževne vrtove). Ena glavnih prednosti deževnih vrtov, bogatih z rastlinskimi vrstami, je ta, da zaradi koreninskega sistema lahko ohrani porozno zgradbo tal in s tem omogoča prosto odtekanje vode skozi plasti. Zaradi samouravnalne zmožnosti takšnih rastlinskih združb so deževni vrtovi nezahtevni za vzdrževanje in posledično cenejši. Zeleni prostori, bogati z rastlinskimi vrstami, krepijo biotsko raznovrstnost na vseh ravneh, so privlačni ter izboljšujejo zdravje in počutje mestnih prebivalcev (slika 7).

\subsection{Poskusna uporaba sistema podnebno odzivnih uličnih vrtov}

Omenjena metoda se trenutno uporablja v okviru raziskovalnega projekta KLAR (nem. Klima Anpassungsregionen), ki poteka v občini Wolfsberg na avstrijskem Koroškem. Izbrana je bila zato, ker se ujema s ciljem projekta, tj. razviti in izvajati metode za obvladovanje vplivov podnebnih sprememb na mestnih območjih. Z interdisciplinarno analizo, ki jo je poleti 2020 opravila delovna skupina, je bilo v neposredni bližini glavne železniške postaje v Wolfsbergu izbrano območje, na katerem bi lahko metodo učinkovito izvedli v okviru pilotnega projekta. Območje ima velik delež neprepustnih površin (95\%), zaradi temperatur, ki so med najvišsimi v okrožju, pa je izpostavljeno učinkom mestnega toplotnega otoka. Hkrati je območje pred železniško postajo pomembno prometno vozlišče in poslovno središče, ki bo $\mathrm{z}$ načrtovanim dokončanjem nove železniške proge Koralm leta 2025 postalo še pomembnejše. Izvedba pilotnega projekta je načrtovana v letu 2021.

Nameščeno bo omrežje stacionarnih mobilnih senzorjev, ki bodo merili toplotno udobje pred izvedbo ukrepov in po
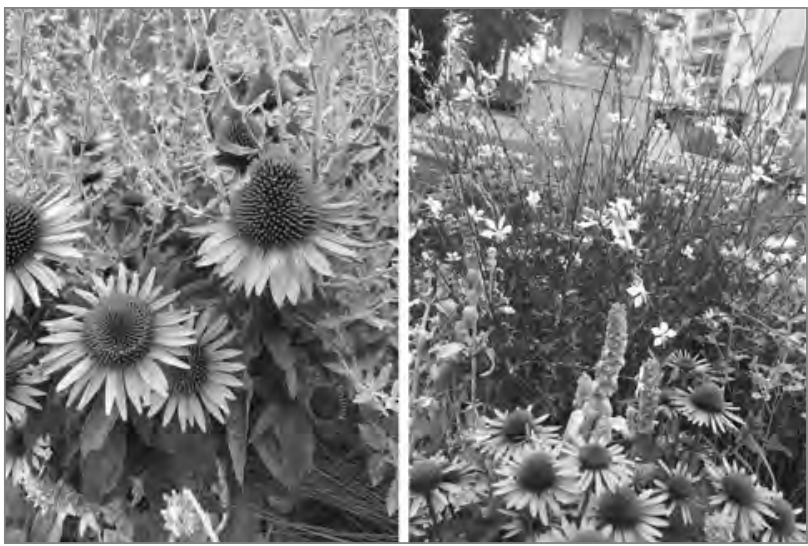

Slika 6: Zahteve sodobnih mestnih zasaditev: visoka estetska vrednost, biotska raznovrstnost in nezahtevno vzdrževanje (vir: avtorji)

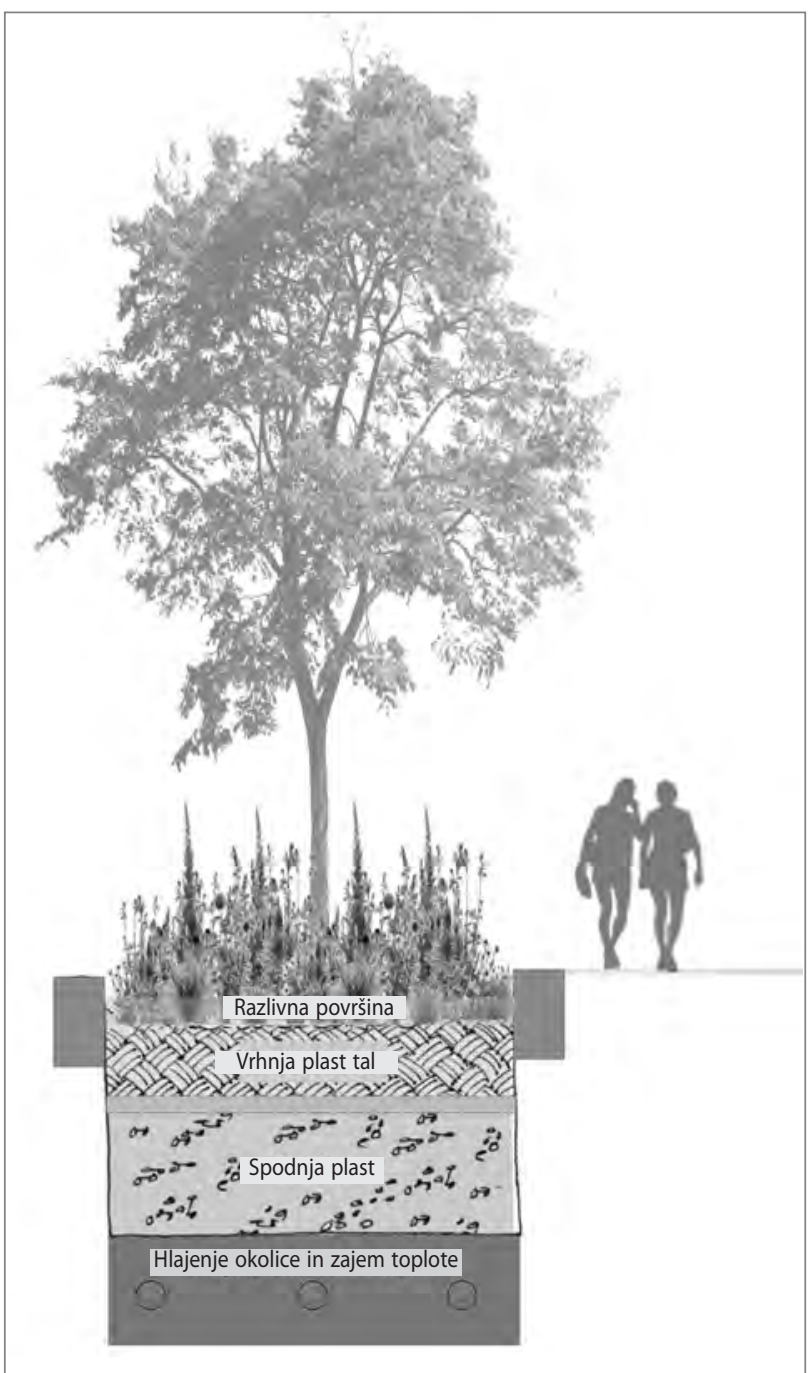

Slika 7: V gramoznih vrtovih so tla dobro prepustna, kar omogoča hitro odtekanje površinske vode (vir: avtorji) 
njej. Začetna faza projekta temelji na preobrazbi že obstoječe zelene površine tik pred vhodom v železniško postajo v približno $200 \mathrm{~m}^{2}$ velik deževni vrt. Območje, izbrano za ureditev deževnega vrta, bo nekoliko spremenjeno, da bo lahko površinska voda odtekala $\mathrm{v}$ na novo urejena tla. Obstoječa monokulturna zasaditev bo zamenjana z mešanico trajnic in trave, pri čemer bodo uporabljene primerne avtohtone vrste, odporne proti suši in občasnemu poplavljanju. Cilj je ohraniti sprejemljiv estetski videz ob hkratnem zagotavljanju čim večje biotske raznovrstnosti v mestnem okolju. Če bo izvedeni poseg uspešen, bo razširjen še na druga območja. Med izvajanjem projekta se bodo poleg tega spremljali tudi učinki nove prostorske ureditve (znižanje temperatur in sprejetost v javnosti).

\section{Razprava in naslednji koraki}

Začetni rezultati so prvi korak v razvoju metode in dajejo trdno podlago za nadaljnji napredek. Jasno je, da je potrebnega še veliko dela za razvoj širše uporabnega sistema. Predvideni naslednji koraki so predstavljeni v nadaljevanju.

Senzorji se lahko uporabljajo kot stacionarne ali mobilne enote. To v primerjavi s trenutno uveljavljenimi modeli, ki uporabljajo letalske posnetke ali posnetke, narejene z brezpilotnimi letalniki, omogočajo največjo prožnost pri cenovno ugodnem rednem zbiranju podatkov o toplotnem udobju (Soto-Estrada idr., 2017). Glavna prednost predstavljenega sistema je ta, da zagotavlja neprekinjen dotok podatkov, kar omogoča celovitejši vpogled $\mathrm{v}$ spreminjajoče se lokalne podnebne razmere. Izkazalo se je, da potreba po namestitvi dodatne naprave na kolo ovira bolj razširjeno uporabo. Dodatna pomanjkljivost je, da trenutni modul ni odporen proti vremenskim vplivom, kar onemogoča njegovo stalno namestitev. Prihodnji razvoj se mora torej osredotočiti na vključitev senzorja med dodatke za kolesa, kot je na primer zvonec, ali pa njegovo integracijo v okvir kolesa. Ob nizki ravni napolnjenosti baterije je bila opažena manjša izguba podatkov, zato je v prihodnje načrtovan razvoj modula na sončne celice, ki bo omogočal neprekinjeno uporabo brez polnjenja. Upravi avstrijske Štajerske je bila poslana prošnja za subvencioniranje razvoja takšnega modula, ki je trenutno v fazi pregleda. Podatki so za zdaj prikazani na prosto dostopnih spletnih uličnih zemljevidih. Naslednji korak v razvoju modula bo zagotovitev natančnejšega ogleda ali zumiranja na ulično krajino za določitev točnega izvora meritev, kar pa zahteva bolj dodelan pristop k oblikovanju informacij.

Osnovni model GIS-orodja za odločanje je že oblikovan in bo preizkušen v naslednjem koraku. Izziv bo združevanje heterogenih podatkov številnih deležnikov v koherenten model. Podatki o toplotnem udobju, zbrani z mobilnimi ali stacionarnimi senzorji, ne bodo težava, saj se lahko zahtevam orodja prilagodijo že pri viru.
Standardizirana oblika zasaditve je bila izbrana na podlagi zahtev o estetskem videzu, biotski raznovrstnosti in odpornosti ter na podlagi izsledkov o rastlinah za gramozne vrtove, ki niso zahtevne za vzdrževanje, in tehnologije deževnih vrtov. $\mathrm{V}$ naslednjem koraku se bo preverjala primernost rastlinskih združb za uporabo na ulici. Terensko preverjanje bo potekalo dve do tri rastne sezone, da se lahko rastline dobro ukoreninijo. Proučevali se bodo odpornost rastlin proti daljšim obdobjem izpostavljenosti visokim temperaturam in pomanjkanju padavin, pogostost potreb po vzdrževalnih posegih, odziv na onesnaženje površinske vode zaradi prometa in zimskega posipanja ulic s soljo ter privlačnost zasaditve in njena posledična sprejetost med ljudmi. Načrtovana je tudi ekološka presoja vplivov na biotsko raznovrstnost na izbranem območju (tj. raznolikost in število opraševalnih žuželk). Na podlagi dobljenih rezultatov bo način zasaditve ustrezno izboljšan.

Sodobna hidrološka in hidrodinamična simulacijska orodja omogočajo oblikovanje in proučevanje decentraliziranih naravi prijaznih strategij gospodarjenja s padavinskimi vodami na različnih mestnih ravneh, od manjših deževnih vrtov do strategij na ravni celotnega mesta. Pomemben dejavnik je čedalje večja razpoložljivost prostorskih in hidrometeoroloških podatkov, na podlagi katerih se lahko ovrednotita učinkovitost in uspešnost strategij gospodarjenja s padavinskimi vodami. Rezultati hidrološke in hidrodinamične simulacije so se izkazali za ključne vhodne podatke za odločevalsko orodje GIS.

V okviru poskusnega projekta $\mathrm{v}$ mestecu Wolfsberg so bili podnebno odzivni ulični vrtovi prvič opredeljeni kot način vključevanja občutno širše funkcionalnosti v neposredno odzivanje na razne izzive, ki jih mestu povzročajo podnebne spremembe, kot je to običajno pri večini obstoječe zelene mestne infrastrukture. Zato je smiselno, da se pojem vrt v pomenu vidne zasaditve kot estetske in hladilne prvine razširi tudi na nevidni prispevek podzemnih plasti, ki so oblikovane tako, da opravljajo raznovrstne pomembne funkcije v mestnem okolju. Poleg tega podnebno odzivni ulični vrtovi ozaveščajo ljudi o pomenu zelene infrastrukture $\mathrm{z}$ vidika dolgoročnega zagotavljanja biotske raznovrstnosti ter telesnega in duševnega zdravja. So pravi mestni zeleni sistem (Wallace, 1990), ki deluje na vseh ravneh.

Pomemben vidik spremljanja učinkov izvedenega posega je tudi določitev ravni javne sprejetosti tovrstne večfunkcionalne zelene infrastrukture in ugotavljanje, ali dodatna funkcionalnost, ki omogoča neposredno prilagajanje na podnebne spremembe, lahko vpliva na večjo javno podporo. Ureditev podnebno odzivnih uličnih vrtov ustvarja dodano vrednost različnim vidikom sedanjega in prihodnjega mestnega življenja. Na podlagi integriranih načel urejanja zelene infrastrukture (Monteiro idr., 2020) predstavljeni pristop omogoča optimal- 
no in trajnostno uporabo virov, kot sta prostor in voda, saj razbremenjuje mestne sisteme za ravnanje z odpadno vodo, kar zmanjšuje neposredne stroške in šciti naravne vodotoke. Ponuja samouravnalno in za vzdrževanje nezahtevno rešitev blaženja vplivov podnebnih sprememb, pri čemer $\mathrm{z}$ uporabo zasaditev, prilagojenih razmeram na izbranem območju in bogatih z rastlinskimi vrstami, povečuje biotsko raznovrstnost v mestu (Mody idr., 2020). Prostorska preureditev ulice z vključitvijo zelene infrastrukture $\mathrm{v}$ tej obliki lahko krepi tudi psihološko počutje na podlagi uporabe načel hortikulturne terapije v javnem prostoru (Ulrich, 1984; Kaplan in Kaplan, 1989) in spodbuja aktivno mobilnost (hojo in kolesarjenje) v privlačnejšem okolju, ki ga ustvarjajo nove zelene površine (Fallast, 2017; Dunnett, 2019). Poleg tega javnemu prostoru omogoča, da ustvari svojo identiteto (Pansinger, 2019).

Navedeni pristop dokazuje še, da velika mesta ne potrebujejo vedno samo velikih projektov. Pogosto prav manjši projekti, kot so urbane akupunkture, povzročajo pomembne spremembe in omogočajo inovacije (slika 8 ).

\section{Sklep}

Večfunkcionalni podnebno odzivni ulični vrtovi so namenjeni predvsem preureditvi ulične krajine ( $\mathrm{t} j$. javnega prostora). V začetni fazi naj bi se urejali zlasti na asfaltnih območjih cest, ki niso namenjena motoriziranemu prometu ( $\mathrm{t} j$. v mrtvih conah brez posebne prometne funkcije), da bi jih javnost čim lažje sprejela. Pomemben del procesa je tudi ozaveščanje ljudi o tem, da cest ne bi smeli dojemati samo kot cestno povezavo, ampak bi jih morali razumeti in uporabljati kot javni prostor in temeljno dobrino mestnih ekosistemov.

Cilj pristopa, predstavljenega v članku, je zato ponuditi inovativno rešitev na podlagi oblikovanja sistematičnega postopka izvajanja zelenih posegov $\mathrm{v}$ javnem mestnem prostoru $\mathrm{z}$ uporabo:

- orodja za oceno primernosti, ki temelji na GIS in združuje vse podatke, potrebne za izbor lokacije in vrste zelene infrastrukture;

- večfunkcionalnega pristopa ter interdisciplinarne in transdisciplinarne metode izvajanja ukrepov za blaženje vplivov podnebnih sprememb;

- mobilnih senzorjev z GPS-sledenjem za zbiranje podatkov o mikroklimi, ki se nato vnesejo v orodje za presojo primernosti, kar omogoča poceni in neprekinjeno spremljanje dinamičnih mestnih mikroklim; navedeno se razlikuje od trenutnega ad hoc pristopa $\mathrm{k}$ uvajanju zelenih prostorov v mestno okolje kot načina obvladovanja vplivov podnebnih sprememb;

- prožnega sistema, ki zadovoljuje potrebe že izoblikova-
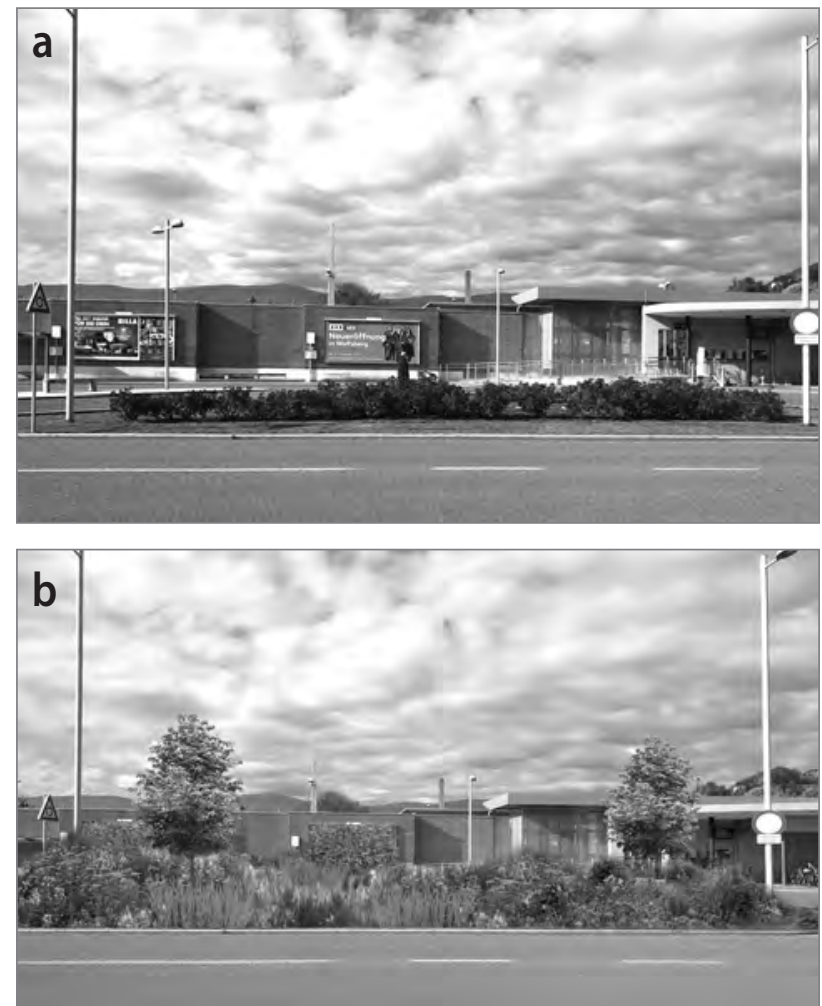

Slika 8: (a) Prostor pred glavno železniško postajo v Wolfsbergu; (b) prikaz istega prostora, preurejenega $v$ večfunkcionalen podnebno odziven ulični vrt (vir: avtorji)

nega mestnega tkiva, ki je pogosto podrejeno strogim prostorskim predpisom in prostorsko omejeno; navedeni sistem ponuja prožne in učinkovite zelene posege (zelene akupunkture), ki lahko na ustrezen način pozitivno vplivajo na lokalne podnebne razmere.

Večfunkcionalni podnebno odzivni ulični vrtovi so prenosljiva metoda preureditve manjših mestnih območij, ki ponuja nov pristop $\mathrm{k}$ barvam, teksturam, globini in funkcionalnosti ter prvine mestnih območij, kot so toplota, padavine, prah in hrup, preoblikuje v novo obliko zelenega.

Marie Therese Fallast, PLANUM Fallast \& Partner GmbH, Gradec, Avstrija

E-naslov:mt.fallast@planum.eu

Sanela Pansinger, Adasca, Gradec, Avstrija

E-naslov: sanela.pansinger@adasca.org

Gerald Krebs, University of Technology, Institute of Hydraulic Engineering and Water Resources Management, Gradec, Avstrija E-naslov: gerald.krebs@tugraz.at

Martin Moser, Quadratic GmbH, Gradec, Avstrija E-naslov:martin.moser@quadratic.at

Andreas Zobl, Quadratic GmbH, Gradec, Avstrija E-naslov: andreas.zobl@quadratic.at 


\section{Viri in literatura}

Chatto, B. (2000): Drought-resistant planting - Lessons from Beth Chatto's gravel garden. London, Francis Lincoln.

Christiaanse, K. (2018): Collected text on the built environment 1990 2018. Rotterdam, NAI010 Publishers.

Dunnett, N. (2019): Naturalistic planting design - The essential guide. Bath, Filbert Press.

Fallast, M. T., in Fallast, K. (2017): Active mobility as part of a sustainable mobility masterplan. Towards a humane city VI. Raziskovalno poročilo. Novi Sad, Faculty of Technical Sciences.

Fallast, M. T. (2018): Category 3: urban gardening - Creative gardening in the city. Dostopno na: https://www.naturimgarten.at/files/ content/3.\%20VERANSTALTUNGEN/DIV/Award/Kategorie $\% 203 \% 20$ PDFs/3\%20Marie-Therese\%20Fallast\%20EN.pdf (sneto 2. 12. 2020).

Fuskova, V., Stepankova, R., in Fuska, J. (2017): GIS analysis of potential locations for rain gardens in village Alekšince. Prispevek je bil predstavljen na konferenci z naslovom MendelNet 2017, ki je potekala od 8. do 9. novembra v Brnu. Tipkopis.

Gehl, J. (2015): City for people. Berlin, Jovis Verlag.

Hitchmough, J. (2017): Sowing beauty: Designing flowering meadows from seed. Portland, OR, Timber Press.

IPBES (2019): Global assessment report on biodiversity and ecosystem services of the Intergovernmental Science-Policy Platform on Biodiversity and Ecosystem Services. Bonn, IPBES Secretary.

Internet 1: https://livingroofs.org/graz-green-infrastructure/ (sneto 22. 2. 2021).

Internet 2: https://www.georgetownclimate.org/adaptation/toolkits/green-infrastructure-toolkit/implementing-pilots-best-practices-and-tools. html (sneto 21. 2. 2021).

Isbell, F., Adler, P. R., Eisenhauer, N., Fornara, D., Kimmel, K., Kremen, C., idr. (2017): Benefits of increasing plant diversity in sustainable agroecosystems. Journal of Ecology, 105, str. 871-879.

DOI: $10.1111 / 1365-2745.12789$

Kaplan, R., in Kaplan, S. (1989): The experience of nature: A psychological perspective. Cambridge, Cambridge University Press.

Kaynakli, O. (2011): Parametric investigation of optimum thermal insulation thickness for external walls. Energies, 4(12), str. 913-927. DOI: 10.3390/en4060913

Koc, C. B., Osmond, P., in Peters, A. (2018): Evaluating the cooling effects of green infrastructure: A systematic review of methods, indicators and data sources. Solar Energy, 166, str. 486-508.

DOI: 10.1016/j.solener.2018.03.008

Kozamernik, J., Rakuša, M., in Nikšič, M. (2020): Vpliv ozelenjenih fasad na zaznavanje urbanih okolij - primerjava med Slovenijo in Nizozemsko. Urbani izziv, 31(2), str. 26-38.

DOI: 10.5379/urbani-izziv-2020-31-02-003

Krebs, G., Kokkonen, T., Valtanen, M., Koivusalo, H., in Setälä, H. (2013): A high-resolution application of a stormwater management model (SWMM) using genetic parameter optimization. Urban Water Journal, 10(6), str. 394-410. DOI: 10.1080/1573062X.2012.739631

Krebs, G., Kokkonen, T., Valtanen, M., Setälä, H., in Koivusalo, H. (2014a): Spatial resolution considerations for urban hydrological modelling. Journal of Hydrology, 512, str. 482-497.

DOI: $10.1016 /$ j.jhydrol.2014.03.013
Krebs, G., Kokkonen, T., Valtanen, M., in Koivusalo, H. (2014b): Large-scale urban hydrological modelling at high spatial resolution: requirements and applications. V: Marchettini, N., Brebbia, C. A., Pulselli, R., in Bastianoni, S. (ur.): The sustainable city IX, str. 1593-1603. Southampton, Združeno kraljestvo, WIT Press. DOI: 10.2495/SC141352

Kristl, Ž., Senior, C., in Temeljotov Salaj, A. (2020): Ključni izzivi prilagajanja podnebnim spremembam v gradbenem sektorju. Urbani izziv, 31(1), str. 40-50. DOI: 10.5379/urbani-izziv-2020-31-01-004

Leimgruber, J., Krebs, G., Camhy, D., in Muschalla, D. (2019): Model-based selection of cost-effective low impact development strategies to control water balance. Sustainability, 11(8), 2440.

DOI: $10.3390 /$ su 11082440

Manso, M., in Castro-Gomes, J. P. (2015): Green wall systems: A review of their characteristics. Renewable and Sustainable Energy Reviews, 41, str. 863-871. DOI:10.1016/j.rser.2014.07.203

Markvica, K., Millonig, A., Leodolter, M., in Haufe, N. (2020): Promoting active mobility behavior by addressing information target groups: The case of Austria. Journal of Transport Geography, 83, 102664. DOI: 10.1016/j.jtrangeo.2020.102664

Mody, K., Lerch, D., Müller, A. K., Simons, N. K., Blüthgen, N., in Harnisch, M. (2020): Flower power in the city: Replacing roadside shrubs by wildflower meadows increases insect numbers and reduces maintenance costs. PLOS One, 15(6). DOI: 10.1371/journal.pone.0234327

Monteiro, R., Ferreira, J. C., in Antunes, P. (2020): Green infrastructure planning principles: An integrated literature review. Land, 9, 525. DOI: 10.3390/land9120525

Pansinger, S. (2018): How much density do we really need? Part I. V: Petersson, P., Kickenweitz, P., Linortner, C., in Krejs, B. (ur.): Intensified density - A small scape densification strategy with using modular construction, str. 44-49. Gradec, Verlag der Technischen Universität Graz.

Pansinger, S. (2019): World heritage and gestalt sustainability. ISG Magazin, 2, str. 26-30.

Pansinger, S., in Förster, J. (2018): Airport neighborhood as future regional development areas for resource awareness and gestalt sustainability. V: Brebbia, C. A., Marchettini, N., in Passerini, G. (ur.): WIT transactions on ecology and the environment: Sustainable development and planning $X$, str. 259-268. Southampton, Združeno kraljestvo, WIT Press. DOI: $10.2495 /$ SDP180241

Shuster, W. D., Bonta, J., Thurston, H., Warnemuende, E., in Smith, D. R. (2005): Impacts of impervious surface on watershed hydrology: A review. Urban Water Journal, 2(4), str. 263-275. DOI: 10.1080/15730620500386529

Smith, L. (2019): Tapestry lawns: Freed from grass and full of flowers. Boca Raton, FL, CRC Press. DOI: 10.1201/9780429263217

Soto-Estrada, E., Correa-Echeverri, S., in Posada-Posada, M. I. (2017): Thermal analysis of urban environments in Medellin, Colombia, using an unmanned aerial vehicle (UAV). Journal of Urban and Environmental Engineering, 11(2), str. 142-149. DOI: 10.4090/juee.2017.v11n2.142149

Sprung, W., Krebs, G., Beutle, K., in Muschalla, D. (2017): Maßnahmenkarte zur grundwasseranreicherung Stadt Graz. Gradec, Aqua Urbanica.

Ulrich, R. S. (1984): View through a window may influence recovery from surgery. Science, New Series, 224(4647), str. 420-421. DOI: $10.1126 /$ science.6143402

Wallace, A. (1990): The green machine: Ecology and the balance of nature. Oxford, Blackwell.

Willenbrock, H. (2020): Die gestresste Stadt. Dostopno na: https://www. brandeins.de/magazine/brand-eins-wirtschaftsmagazin/2020/wie-wollen-wir-leben/die-gestresste-stadt (sneto 21. 2. 2021). 
Wood, E., Harsant, A., Dallimer, M., Cronin de Chavez, A., McEachan, R. R. C., in Hassall, C. (2018): Not all green space is created equal: Biodiversity predicts psychological restorative benefits from urban green space. Frontiers in Psychology, 9. DOI: 10.3389/fpsyg.2018.02320

Xuexiu, Z., Yanwen, L., in Jiang, H. (2020): Analysis of the thermal environment in pedestrian space using 3D thermal imaging. Energies, 13(14), 3674. DOI: 10.3390/en13143674 